\title{
SUMMARY OF CHANGES IN TIMBER DISPOSAL REGULATIONS IN CANADA THROUGH THE 2-YEAR PERIOD, $1935-36$
}

\author{
$B y$ J. R. Dickson \\ Dominion Forest Service
}

$I^{N}$

N CANADA, the year 1935 saw the production of both lumber and newsprint-chief products of the two great forest industries-almost or quite back again to normal, average figures, although unhappily the same cannot be said for the financial returns. One gratifying result, however, was the increased employment given to workers, both in the woods and mills. This story of steadily rising output and wage scales has been a still more marked feature of 1936. The newsprint mills are once more back to a full-time production basis.

All through 1935 and part of the present year, the forest industries were kept confused and uncertain pending Supreme Court decisions on the validity of an ambitious federal program of marketing and social welfare legislation. Finally it was in a large part disallowed and ceased to be a disturbing influence affecting every forest-owning province.

In May, 1935, Section 22 of the Dominion Weights and Measures Act was amended to establish a standard legal cord of 128 cubic feet, for the measurement of forest products throughout Canada. This should avoid nuch confusion by eliminating the various-sized cords used in the past by Governments, operators, farmers and jobbers.

\section{NOVA SCOTIA}

For some years previous to 1933 , this province had a flat stumpage 1 ate of $\$ 2.00$ per $M$ for saw material and $\$ 1.00 \mathrm{per}^{\mathrm{c}}$ cord for pulpwood. Then for two years a sliding scale was tried which varied the stumpage in accordance with the relative quality and accessibility of the timber being sold. The range was from $\$ 1.20$ to $\$ 3.00$ per $M$ and 60 cents to $\$ 1.50$ per cord. This was partly a relief measure and with the return of better times in 1935 the rate was made uniform, and fixed at $\$ 3.00$ per $M$ and $\$ 1.50$ per cord. The New Brunswick log rule is now the only scale used on Crown timber. No change in regulations has been reported for 1936 .

It will be recalled that in 1930 an attempt was made in Nova Scotia to establish an effective measure of government control over private logging operations. In the interval, however, this much-needed legislation has been repealed and nothing more heard of the proposal.

\section{NEW BRUNSWICK}

In August, 1935, a number of changes in rates and regulations were announced, covering the cutting season of 1935-36; chiefly as follows: 
Stumpage-White Pine increased 50c per $M$ over 1934 rate, e.g., to $\$ 3.00$. Beech logs reduced from $\$ 2.00$ to $\$ 1.50$ per M. Hewn softwood ties reduced from $12 \mathrm{c}$ to $10 \mathrm{c}$ per tie. On all other products the $1934-35$ rate was unchanged. It was decided that the fixed stumpage rates on 50 -year licenses though higher than current rates, must remain in effect.

In September, 1936, action was taken to continue the existing Crown dues to cover the 1936-37 season cut, "in order to stimulate industry and provide work and wages, thus assisting both Capital and labor."

Regulations-A licensee must no longer charge a purchaser of stumpage from his berth, more than 50 per cent in advance of government dues. Moreover this limitation now applies to all species and products.

In 1935 the siandard cord of 128 cubic feet was adopted as the basic legal unit for the measurement of all corded products. While pulpwood may still be cut in log lengths and scaled in board feet, the dues are fixed, on the pro-rated basis of $2 \frac{1}{2}$ cords of peeled, 4 -foot wood equals 100 board feet by N. B. scale, these respective quantums having been found to yield equivalent amounts of wood pulp.

A licensee was given 3 years instead of one in which to remove the timber from a homestead lot on his berth, and on this work the homesteader himself must now be given employment.

The plan of cutting by exception on "Undersize Permit" areas was extended to certain news classes of Crown lands under licence, with the cut not to exceed the net annual growth. Upon the whole, New Brunswick continues to make good progress toward better forest management.

\section{ONTARIO}

It continues to be difficult to determine just what is happening in Ontario forests when it comes to the test of securing minimum silvicultural requirements through logging procedure. No significant changes in timber disposal methods took place in 1935.

The marked reduction in royalty dues and bonuses made applicable to the 1934-35 season cut in Ontario, was renewed for the 1935-36 cut, and again recently for the 1936-37 production. Further, in 1935, the dues on spruce pulpwood were lowered from $\$ 1.40$ down to $\$ 1.00$ per cord. In the same year, a change in policy resulted in the Order-in-Council of July 24, which permitted the export of pulpwood from Crown lands under certain conditions designed to safeguard the Canadian paper industry. Furthermore, collection of the export tax of 25c a cord was waived. In May 1936, this provision for export of pulpwood was renewed for the 1936-37 cut.

In April, 1936, the important "Forest Resources Regulation Act" was passed in Ontario. It is patterned after the similar Quebec Act and designed 
chiefly to give the government closer control of the supply of pulpwood on berths, both for domestic use and export. Under its application the cut of pulpwood on Crown lands will be largely increased during the coming winter, and is expected to reach a figure in excess of 700,000 cords.

It is encouraging to note that as the result of a meeting on October $17 \mathrm{th}$, 1936, the premiers of Ontario and Quebec arrived at a co-operative understanding expressed by Premier Hepburn as follows (re press report): "We are going to co-ordinate the entire administration of our Lands and Forests departments in a joint effort to further de velop our natural resources. There will be uniformity in respect particularly to wages, labor conditions, cutting operations and timber conservation methods."

Surely both foresters and forest-users will agree that this initial effort to correlate and so far as possible standardize timber disposal regulations in eastern Canada is long overdue and all to the good, seeing that the sale price of lumber or paper is set in a common world market.

\section{QUEBEC}

During 1935, no very outstanding changes took place in the Quebec timber regulations. However, a revised code of scaling procedure on Crown lands was laid down in a new, 40-page manual. In general, this thorought revision besides establishing uniformity of procedure, comprehended an effort on the one hand to ensure that all forest workers shall recejve equitable wages, and on the other to secure to the Crown a more prompt and full collection of stumpage dues from all operators concerned. This manual was revised in 1936, and may be obtained on request.

Two laws were passed in Quebec in 1935, which more or less directly affect the disposal of timber. Most important is the "Forest Resources Protection Act," designed to further protect forest workers and government revenues from the evil effects of wasteful and uncconomic exploitation of timber. It provides very stiff penalties, in the form of sharply increased stumpage dues, for companies which persist in infringing the cutting regulations. The second law, the "Settlers Wool-selling Assistance Act," empowers the Forest Products Commission to actively assist farmers in finding a market for their woodlot prodlucts.

The final adoption of the cubic foot as the legal unit of measurement for all forest products, has madc 1936 a red-letter year in Quebec forestry annals. On June 3rd, 1936, an Order-in-Council adopted the cubic foot "as the exclusive unit of measurement for woods to be cut on Crown lands, from May 1st, 1936."

The new schedule of Crown dues framed on this basis, may now be obtained on request. For round timber, whether logs or bolts, of any length, the 
unit of $100 \mathrm{cu} . \mathrm{ft}$. of solid wood is conveniently employed. For all stacked wood (embracing pulpwood, fuelwood, spoolwood, lath bolts and shingle bolts) the standard cord of 128 cubic feet may be used in scaling. The present stumpage rate on pulpwood is the same whether paid on a cunit or a standard cord, namely $\$ 1.20$. Although cunit scaling, being by the piece, costs more than standard cord measurement, several paper companies will employ it this winter. They believe that a profit may thus be made, inasmuch as the average cord of pulpwood contains about 85 cubic feet of solid wood. The idea is that for the same royalty payment, they will get a one-sixth greater volume of wood.

All Canadian foresters will observe with interest the practicability of scaling saw logs under cubic foot measurement. So far as pulpwood is concerned, the change to all cubic measurement should reflect a considerable increase in governmental revenue, as the old board-foot unit admittedly brought not a little "cream and gravy" to the operating companies.

On the coming winter's cut of saw logs a reduction of the June, 1936, rates was effected by Order-in-Council 2759 of October 13th, which sets the following royalties:

Stumpage Rate per $100 \mathrm{cu}$. ft. of Species solid wood.

Elm, Ash, Basswood, Maple and Yellow Birch .................... \$1.00

White, Red and Jack Pines ........................................ $\quad .85$

Spruce, Balsam, Larch, Cedar and White Birch .................. $\quad .75$

Hemlock and Poplar ..................................................... $\quad .60$

It is further provided that the cubic contents of all saw-logs cut before May 1st, 1937, shall be based on the diameter at small end of the log. The Department ,however, requires each operator to furnish also a check scale, based on the average of both end diameters.

For the coming winter of 1936-37, all Pulp and Paper Companies in Quebec are required to pay their woods workers a minimum wage of $\$ 40$ a month.

\section{THE PRAIRIE PROVINCES}

Practically no important changes in timber regulations or woods practice were reported from this section of Canada in 1935 or during the present year. The existing procedure appears to be giving fair satisfaction, and in particular the use of the International Log Rule in Manitoba and Saskatchewan. In reply to an enquiry as to how they liked this log scale, the Provincial Foresters in these provinces replied almost in the same words: "We find this rule most satisfactory in actual use. We are convinced it is the best rule to use and certainly have no regrets over having adopted it." In a few years' time, 
unless meanwhile the Quebec cubit-foot unit finds general adoption this almost perfect $\log$ rule will no doubt be the only one used between Halifax and the Rockies, with the "Doyle" in particular, only an evil memory.

\section{BRITISH COLUMBIA}

No material changes in timber disposal and cutting regulations have been reported from the Sunset Province during this year or last. 'The situation is that for several years past the Forest Authority has been obliged by prevailing economic conditions to largely hold in abeyance, the application to current lumbering operations of their fine code of forest laws. After all, the far-reaching "law of the margin" governs, and to have required B. C. Crown land operators to practice approved forestry methods, while their close market competitors south of the line were cutting as they liked on private lands, would have put most of them "into the red." Now, with better times returning, this regrettable situation will no doubt be overcome.

Another factor helping toward better silvicultural practice, not only in B. C., but everywhere west of the lakes, is the increasing proportion of the total cut of saw timber which is coming from "Timber Sale" areas. For instance in B.C. in 1930, this proportion was about 10 per cent, while in 1936, it will reach 25 per cent.

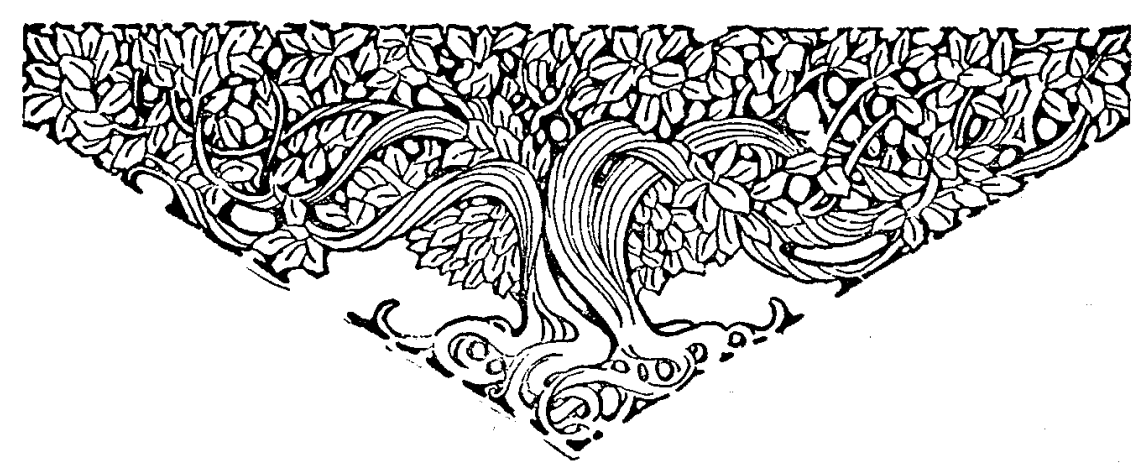

